\title{
PENGARUH PENAMBAHAN EKSTRAK BUAH NAGA (Dragon Fruit) SEBAGAI PEWARNA ALAMI TERHADAP MUTU FISIK MI SAGU BASAH
}

(The effect of the addition of dragon extract fruit as a natural dye to the physical quality of wet sago

noodle)

\author{
Adnan Engelen \\ Program Studi Teknologi Hasil Pertanian, Politeknik Gorontalo \\ Email: adnanengelen@poligon.ac.id
}

\begin{abstract}
ABSTRAK
Tujuan dari penelitian adalah mengetahui kombinasi terbaik pada pembuatan mi sagu basah dengan penambahan ekstrak buah naga. Metode analisis data yang digunakan yaitu metode RAL (rancang acak lengkap), Parameter yang diamati yaitu warna, kadar air, profil tekstur (kelengketan dan kekerasan) dan uji organleptik. Berdasarkan hasil penelitian, warna mi sagu dengan ekstrak buah naga menunjukkan nilai rata-rata yang tertinggi pada perlakuan A yaitu 332,50, perlakuan B yaitu 331,74, dan perlakuan C yaitu 329,20. Nilai kadar air terendah terdapat pada perlakuan A yaitu 49,09\% sedangkan pada perlakuan B yaitu 50,89\% dan perlakuan C yaitu $51,41 \%$. Tingkat kekerasan pada perlakuan A menunjukkan nilai rata-rata yang tertinggi yaitu 3839 sedangkan perlakuan B yaitu 3040, perlakuan C yaitu 2286. Nilai kelengketan pada perlakuan B yaitu 4,6 sedangkan perlakuan A yaitu 4,58 dan nilai kelengketan terendah pada perlakuan $\mathrm{C}$ yaitu 3,98. Adapun hasil uji organoleptik terbaik pada mi sagu basah adalah perlakuan $\mathrm{C}$ dengan nilai aroma rata-rata 4,4, parameter rasa nilai rata-rata 4,8, parameter tekstur nilai rata-rata 4,9, parameter warna nilai rata-rata 5,13 .
\end{abstract}

Kata kunci: mi sagu; ekstrak; buah naga

\begin{abstract}
The aim of the study was the combination of making wet noodles by addition to dragon fruit extract. The data analysis method used is the RAL method (complete random design), the associated parameters are color, water content, loss of cuisine, adhesiveness and hardness and sensory analysis. Based on the results of the study, the color of sago noodles with 332.50, B treatment was 331.74, and C treatment was 329.20. The lowest water content in handling value is $49.09 \%$ while in treatment $\mathrm{B}$ is $50.89 \%$ and treatment $\mathrm{C}$ is $51.41 \%$. The highest level of violence at the time of administration is 3839 while treatment B is 3040 , handling $C$ is 2286 . The stickiness value in training B is 4.6 while maintenance $\mathrm{A}$ is 4.58 and the lowest stickiness value is when $\mathrm{C}$ is 3,98 While the best organoleptic test results on wet sago noodles are of an average aroma value of 4.4, taste parameters average value of 4.8 , texture parameter average value of 4.9 , color parameter average value of 5,3 .
\end{abstract}

Keywords: sago noodle; extract; dragon fruit

\section{PENDAHULUAN}

Indonesia merupakan salah satu negara yang mempunyai komitmen tinggi terhadap ketahanan pangan. Komitmen tersebut dituangkan dalam undang-undang nomor 7/1996, tentang pangan yang mengamanatkan agar pemerintah bersama masyarakat mewujudkan ketahanan pangan bagi seluruh rakyat Indonesia. Menurut Thahir (2004) sumberdaya alam Indonesia memiliki potensi ketersediaan pangan yang beragam dari satu wilayah ke wilayah lainnya, baik sebagai sumber karbohidrat, protein, vitamin maupun mineral, yang berasal dari kelompok padi-padian, 
umbi-umbian, pangan hewani, kacang-kacangan, sayur, buah, dan biji berminyak.

Tanaman sagu (Metroxylon Sp.), banyak dijumpai di daerah rawa dan pinggir sungai di Indonesia dan terpusat di Papua, Maluku, Sulawesi dan Riau. Tanaman sagu menyimpan pati sebagai cadangan pangan di bagian batang. Manfaat pati sagu selama ini digunakan sebagai makanan pokok dan bagi masyarakat Indonesia. Pati sagu memiliki beberapa kelebihan dibanding tepung terigu, pati sagu mengandung pati yang tidak tercerna yang penting bagi kesehatan pencernaan yang memiliki efek seperti serat makanan. Disamping makanan pokok dari pati sagu dimanfaatkan sebagai makanan cemilan seperti bagea, ongol-ongol, kue bangkit dan sebagainya (Hariyanto, 2011).

Saat ini yang lebih dikenal adalah mi dengan bahan baku tepung terigu, sedangkan mi dengan bahan baku sagu hanya dikenal oleh sekelompok orang pada daerah tertentu. Kandungan karbohidrat yang terdapat pada mi sagu ini memang sangat tinggi yaitu $80 \%$, namun dari kandungan proteinnya sangat minim sekali berdasarkan direktorat gizi, Depkes RI (1990), kandungan protein yang terdapat pada mi sagu yaitu < $0,7 \%$. Hal ini merupakan salah satu faktor pembatas untuk mengembangkan produk-produk makanan berbasis sagu sebagai produk pangan yang bernilai gizi tinggi (Dewita, $d k k$ 2014).

Buah naga super merah (Hylocereus costaricensis) selain dikonsumsi dalam bentuk segar juga diolah menjadi beberapa produk olahan untuk mempermudah mengkonsumsi, karena buah naga adalah buah yang mengandung kadar air tinggi maka bersifat muda rusak oleh karena itu banyak orang yang membuat olahan buah naga untuk mengurangi jumlah kerugian, adapun produk olahan yang diminati antara lain dodol, sirup, dan kripik buah naga super merah (Hylocereus costaricensis), (Wahyuni, 2012).

Zat pewarna makanan adalah bahan tambahan makanan yang dapat memperbaiki atau memberi warna pada makanan. Penambahan pewarna pada makanan dimaksud untuk memperbaiki warna makanan yang berubah atau memucat selama proses pengolahan atau memberi warna pada makanan yang tidak berwarna agar kelihatan lebih menarik (Noviana, 2005).
Zat pewarna makanan merupakan suatu senyawa berwarna yang memiliki afinitas kimia terhadap benda yang diwarnainya. Warna suatu produk makanan ataupun minuman merupakan salah satu ciri yang sangat penting. Warna merupakan kriteria dasar untuk menentukan kualitas makanan, antara lain warna juga dapat memberi petunjuk mengenai perubahan kimia dalam makanan, seperti pencoklatan (Cahyadi, 2009).

Peraturan mengenai penggunaan bahan pewarna yang diizinkan dan yang dilarang untuk pangan diatur melalui SK Menteri Kesehatan RI Nomor 722/Menkes/Per/IX/88 mengenai bahan tambahan makanan, tetapi sering terjadi penyalahgunaan pemakaian bahan pewarna berbahaya untuk bahan pangan, misalnya bahan pewarna untuk tekstil dipakai untuk mewarnai bahan pangan. Hal ini jelas sangat berbahaya bagi kesehatan karena adanya residu bahan pewarna tersebut. Timbulnya penyalahgunaan bahan pewarna disebabkan oleh ketidaktahuan masyarakat mengenai pewarna untuk pangan, dan juga karena harga bahan pewarna untuk industri relatif jauh lebih murah dibandingkan dengan bahan pewarna untuk pangan. Disamping itu warna dari bahan pewarna tekstil biasanya lebih menarik (Yuliarti, 2007).

Zat pewarna makanan merupakan suatu senyawa berwarna yang memiliki sifat kimia terhadap benda yang diwarnainya. Warna suatu produk makanan ataupun minuman merupakan salah satu ciri yang sangat penting dalam menentukan kualitas fisik dan kimia pada suatu produk yang dihasilkan. Sehingga penelitian ini untuk melihat pengaruh penambahan ekstrak buah naga sebagai pewarna alami terhadap mi sagu basah.

\section{METODE PENELITIAN}

\subsection{Tempat dan Waktu Penelitian}

Penelitian ini dilakukan pada bulan Mei 2018 di Laboratorium Teknologi Hasil Pertanian Kampus Politeknik Gorontalo.

\subsection{Bahan dan Alat Penelitian}

Bahan utama yang digunakan adalah pati sagu dan buah naga yang berasal dari pasar sentral di Kota Gorontalo. Bahan tambahan yang digunakan 
dalam proses pembuatan mi sagu kering adalah glyserol monosterate (GMS) dan air galon. Peralatan yang digunakan untuk penelitian ini adalah oven pengering, cetakan mi, alat pengukus, timbangan analitik, cawan porselin, dan peralatan gelas. Oven pengering berbentuk persegi dengan ukuran $100 \mathrm{~cm} \mathrm{x}$ $100 \mathrm{~cm}$.

\subsection{Prosedur Pembuatan Mi Sagu (Modifikasi Engelen, 2017)}

1. Siapkan alat dan bahan yang akan digunakan dalam pembuatan mi sagu.

2. Air dipanaskan di kompor sampai mendidih, kemudian masing-masing pati sagu yang diberi sampel 60\%, 70\%, 80\% ditimbang.

3. Sampel pati sagu dimasukkan ke dalam air sebanyak $200 \mathrm{~mL}$ yang sudah dipanaskan sambil di aduk-aduk sampai sagunya mengental atau tergelatinisasi.

4. Adonan dimasukkan ke dalam loyang yang sudah ada pati sagunya sebanyak $200 \mathrm{~g}$. Kemudian tambahkan ekstrak buah naga dengan perbandingan 20\% ekstrak buah naga.

5. Masukkan GMS pada adonan pati sagu sesuai perlakuan.
M1= Pati sagu 60\% : ekstrak buah naga 15\%: GMS $14.4 \mathrm{~g}$

M2= Pati sagu 70\% : ekstrak buah naga 20\%: GMS $15.3 \mathrm{~g}$

M3= Pati sagu 80\% : ekstrak buah naga 25\% : GMS $16.2 \mathrm{~g}$.

6. Masing-masing perlakuan dicetak dengan menggunakan gilingan atau pencetak mi. Kemudian masukkan mi sagu ke dalam air yang sudah di panaskan selama 10 detik. Angkat kemudian dinginkan mi sagu di bak oven yang sudah di sediakan.

\subsubsection{Analisis Data}

Pada penelitian ini menggunakan perbandingan pati sagu dan GMS $4.5 \%$ dengan air sebanyak $200 \mathrm{~mL}$ dengan penambahan ekstrak buah naga sebanyak $20 \%$ ke dalam pati sagu sebanyak $200 \mathrm{~g}$ dengan perlakuan: $A=$ Pati sagu 60\% : ekstrak buah naga 15\%: GMS $14.4 \mathrm{~g}$

B = Pati sagu 70\% : ekstrak buah naga 20\%: GMS $15.3 \mathrm{~g}$

$\mathrm{C}=$ Pati sagu $80 \%$ : ekstrak buah naga 25\% : GMS $16.2 \mathrm{~g}$

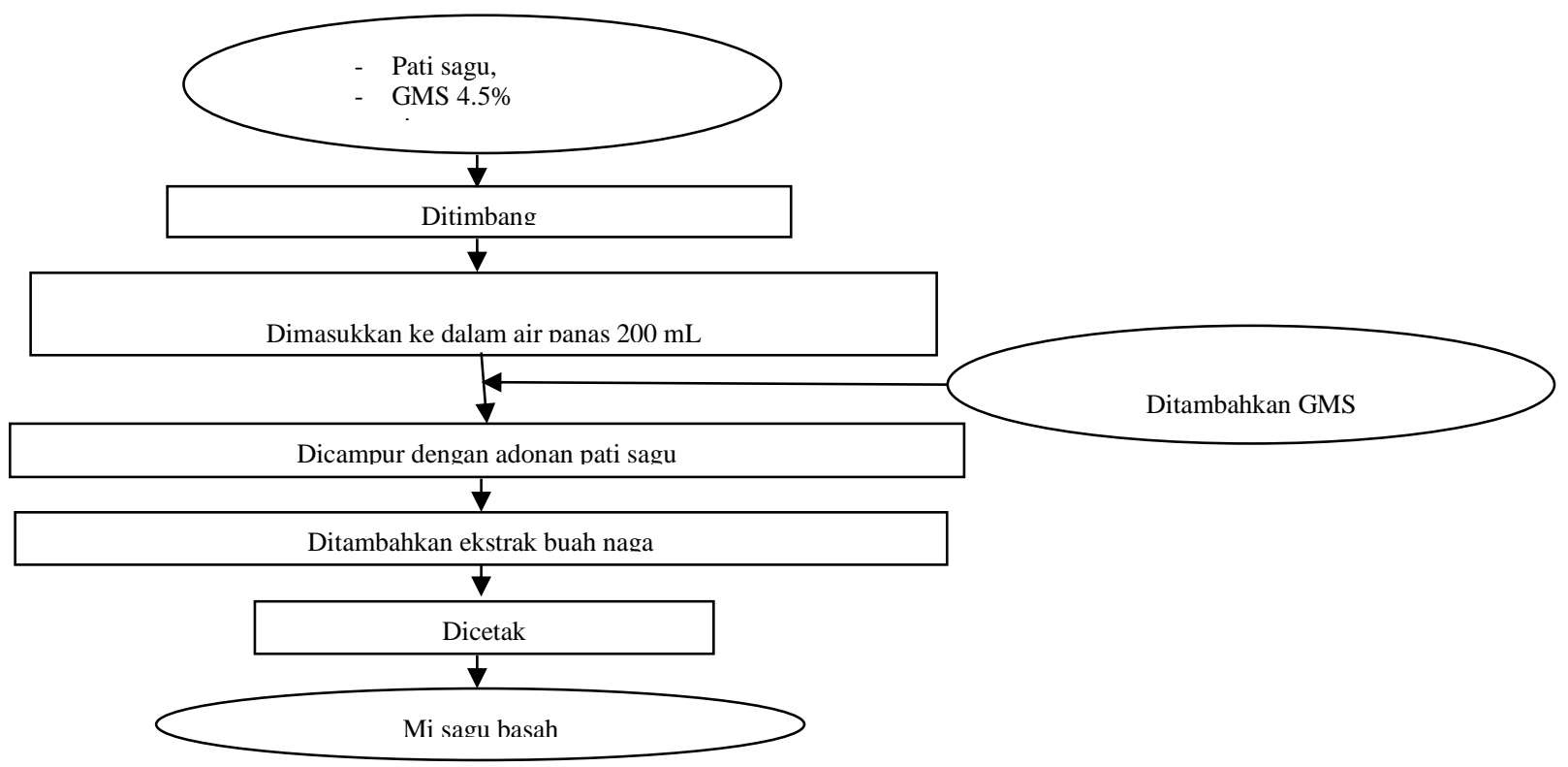

Gambar 1. Diagram alir pembuatan mi sagu dengan penambahan ekstrak buah naga 


\subsection{Prosedur Analisis}

2.4.1. Analisis kadar air (Kurniasari $d k k$, 2015)

Cawan dipanaskan pada suhu $105^{\circ} \mathrm{C}$ selama

15 menit, setelah itu, cawan didinginkan dalam desikator selama 15 menit. Mi yang digunakan adalah mi sagu kering sebanyak 2 gram yang dimasukkan ke dalam cawan porselin yang telah diketahui bobotnya. Cawan berisi sampel tersebut dimasukkan ke dalam oven bersuhu $105^{\circ} \mathrm{C}$ selama 4 jam. Setelah itu, cawan didinginkan dalarn desikator selama 15 menit kemudian ditimbang kembali. Kadar air mi sagu dihitung dengan menggunakan rumus dibawah ini :

$$
\text { Kadar air }(\% \mathrm{bb})=\frac{(x-y)}{(x-a)} \times 100 \%
$$

Ket. $\quad \mathrm{x}=$ berat cawan dan sampel sebelum dikeringkan $(\mathrm{g})$

$\mathrm{y}=$ berat cawan dan sampel setelah dikeringkan $(\mathrm{g})$

$\mathrm{a}=$ berat cawan kosong $(\mathrm{g})$

\subsubsection{Analisis warna}

Pengujian warna dengan menggunakan colorimeter AMT-501. Pengukuran menghasilkan nilai $\mathrm{L}$, a dan $\mathrm{b}$. L menyatakan parameter kecerahan (warna akromatis, 0: hitam sampai 100: putih). Warna kromatik campuran merah hijau ditunjukkan oleh nilai $\mathrm{a}(\mathrm{a}+=0-100$ untuk warna merah, $\mathrm{a}-=0-(-80)$ untuk warna hijau. Warna kromatik campuran biru kuning ditunjukkan oleh nilai $\mathrm{b}(\mathrm{b}+=0-70$ untuk warna kuning, $b-=0-(-70)$ untuk warna biru. Pengujian warna dilakukan sebanyak tiga kali ulangan.

\section{Profil tekstur (kekerasan dan kelengketan)} (Engelen et al. 2015)

Pengujian menggunakan TA-HD-Plus. Probe yang digunakan berbentuk silinder dengan diameter $35 \mathrm{~mm}$. pengaturan TA-HD-Plus yang digunakan adalah sebagai berikut: pre test speed $2,0 \mathrm{~mm} / \mathrm{s}$, test speed $0,1 \mathrm{~mm} / \mathrm{s}$, rupture test distance $75 \%$, mode Texture Profile Analysis (TPA). Seuntai sampel mi dengan panjang yang melebihi diameter probe diletakkan di atas landasan lalu ditekan oleh probe. Nilai kekerasan ditunjukkan dengan absolute (+) peak yaitu: gaya maksimal, dan nilai kelengketan ditunjukkan dengan absolute (-) peak. Satuan kedua parameter ini adalah gram force (gf).

\subsubsection{Analisis Sensori (Pancapalaga, 2005)}

Uji sensori digunakan sebagai standar pengendalian mutu bahan baku, proses produksi, dan produk akhir sehingga diperoleh data yang akurat dalam rangka pengembangan produk yang disukai konsumen dan mampu bersaing dipasaran. Pengujian organoleptik dapat dilakukan dalam berbagai cara, salah satu diantaranya adalah preference test atau uji kesukaan.

Dalam pelaksanaannya, panelis diminta memberikan penilaian dalam skala hedonik yang menunjukan tingkan dari sangat tidak suka sekali sampai sangat suka sekali untuk respon warna, aroma dan tekstur. Misalnya dalam hal suka dapat mempunyai skala hedonik seperti: amat sangat suka, sangat suka, suka, agak suka. Sebaliknya jika tanggapan itu " tidak suka " dapat mempunyai skala hedonik seperti suka dan agak suka, terdapat tanggapannya yang disebut sebagai netral, yaitu bukan suka tetapi juga bukan tidak suka (Kusumawaty, dan Fitriani, 2011).

Uji organoleptik dilakukan pada 30 orang panelis. Parameter yang diuji meliputi rasa, aroma, warna dan tekstur. Umtuk mengetahui hasil produk yang terbaik diantara keempat perlakuan. Uji yang digunakan adalah uji hedonik untuk mengetahui tingkat kesukaan terhadap rasa, aroma, warna dan tekstur. Pada uji hedonik, penilaian dilakukan dengan menggunakan 5 skala numerik, yaitu : sangat suka; suka; biasa/netral; tidak suka; dan sangat tidak suka.

\section{HASIL DAN PEMBAHASAN \\ 3.1. Analisis Warna}

Warna menjadi sangat penting pada produk makanan dan minuman, untuk memberi warna pada makanan dan minuman dapat memberi kesan pada konsumen. Pewarna alami yang digunakan dalam pembuatan mi sagu basah ini yaitu dari ekstrak buah naga karena warna merah muda yang terkandung dalam daging buah naga memberikan daya tarik tersendiri bagi para pencinta mi. Hasil analisa warna 
dapat dilihat pada Gambar 2.

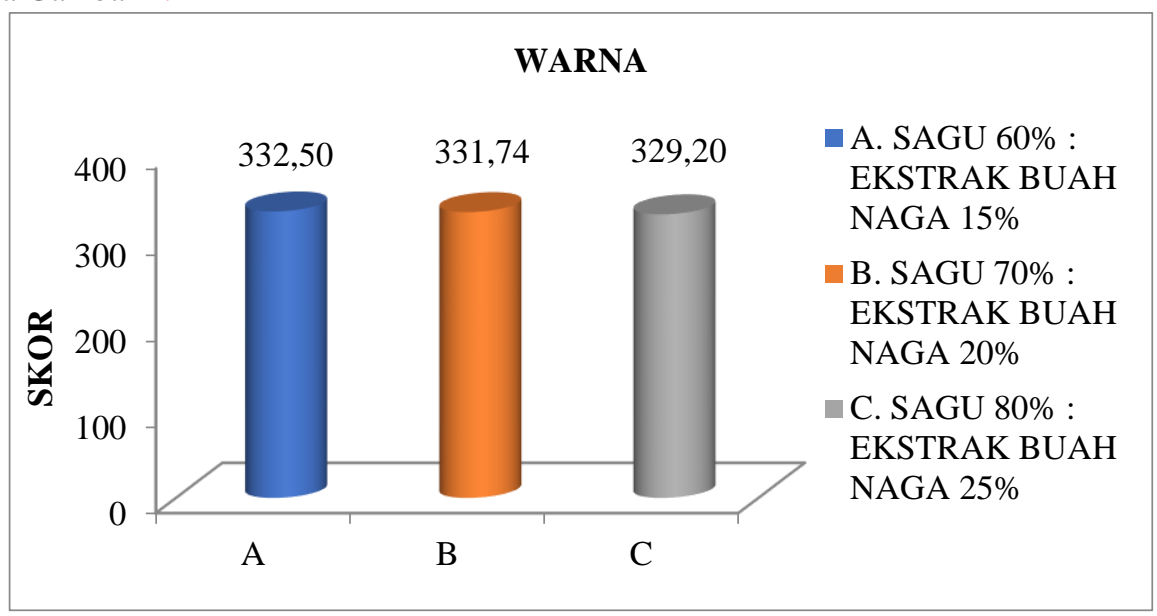

Gambar 2. Warna mi sagu ekstrak buah naga

Pada Gambar 2 menunjukkan perlakuan A memberikan warna yang lebih tinggi (timbul) dibandingkan dengan perlakuan B dan C. Berdasarkan hasil pengujian warna terhadap mi sagu dengan ekstrak buah naga menunjukkan nilai rata-rata yang tertinggi adalah pada perlakuan A yaitu 332.50 dan disusul oleh perlakuan B yaitu 331.74 dan nilai yang terendah berada pada perlakuan C yaitu 329.20.

Zat pewarna alami telah diperoleh melalui proses ekstrak buah naga, hasil ekstrak buah naga dicampurkan pada pati sagu dengan tujuan dapat memberikan warna yang menarik pada mi sagu. Warna merah yang terkandung dalam buah naga memberikan daya tarik tersendiri pada produk yang dihasilkan, campuran buah naga yang 15\% ekstrak buah naga. Pada perlakuan A menghasilkan warna yang lebih baik/timbul dibanding perlakuan yang berikutnya. Menurut Masturi dkk (2016) bahwa hasil ekstraksi warna merah buah naga menunjukkan semakin besar massa ekstraksi buah naga maka semakin pekat warna merah yang dihasilkan. Adapun syarat pengujian nilai hue dapat dilihat pada Tabel 1 .

Tabel 1. Nilai hue dan daerah kisaran (Hutchings, 1999)

\begin{tabular}{cc}
\hline Nilai ${ }^{\text {hue }}$ & Daerah kisaran warna \\
\hline $342^{0}-18^{0}$ & Merah - Ungu \\
$18^{0}-54^{0}$ & Merah \\
$54^{0}-90^{0}$ & Kuning - Merah \\
$90^{0}-126^{0}$ & Kuning \\
$126^{0}-162^{0}$ & Kuning - Hijau \\
$162^{0}-198^{0}$ & Hijau \\
$198^{0}-234^{0}$ & Biru - Hijau \\
$234^{0}-270^{0}$ & Biru \\
$270^{0}-306^{0}$ & Biru - Ungu \\
$306^{0}-342^{0}$ & Ungu \\
\hline
\end{tabular}

\subsection{Kadar Air}

Kadar air yang terkandung dalam suatu produk bahan pangan dapat mempengaruhi kualitas fisik maupun kimia dari produk tersebut. Begitu pula dengan daya penyimpanan suatu produk semakin tinggi kadar air, maka dapat mempermudah 
pembusukkan atau tumbuhnya bakteri. Hasil nalisa kadar air mi sagu ekstrak buah naga, dapat dilihat pada Gambar 3.

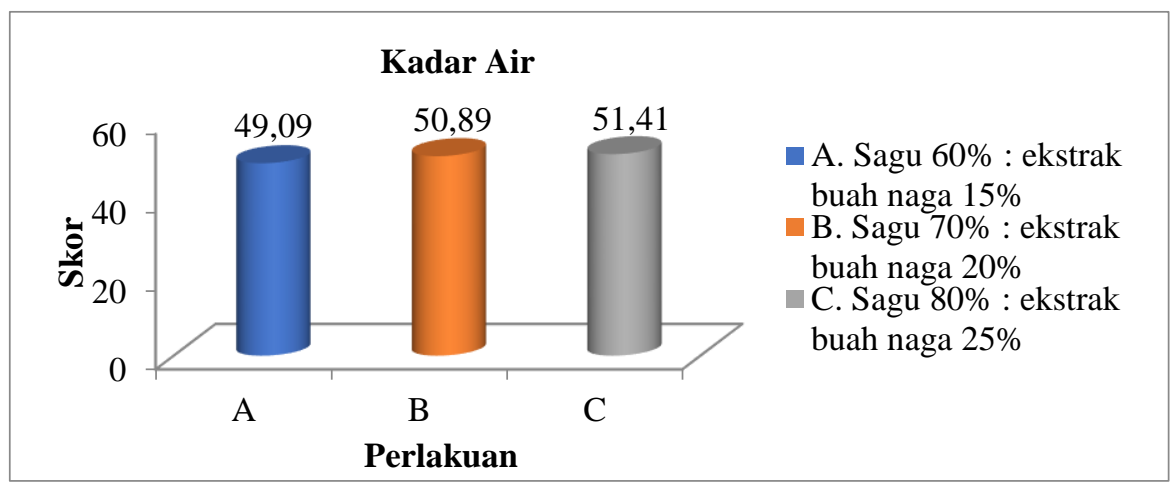

Gambar 3. Kadar air mi sagu ekstrak buah naga

Berdasarkan hasil analisa kadar air yang telah dilakukan pada mi sagu ekstrak buah naga, maka diperoleh nilai $F_{\text {hitung }}(1.11)$ lebih kecil dari $F_{\text {tabel }}(0.05)$ yaitu 5.14 dan $\mathrm{F}_{\text {tabel }}(0.01)$ yaitu 10.92 , dapat diartikan bahwa tidak berpengaruh nyata terhadap kadar air sehingga tidak dilakukan uji BNT. Rendahnya kandungan kadar air ini dapat disebabkan oleh adanya proses pengeringan dalam tanur. Semakin rendah kandungan kadar air maka semakin bagus proses penyimpanan suatu produk, semakin tinggi kandungan kadar air semakin cepat proses pembusukkan.

Kandungan air mi sagu basah terendah terdapat pada perlakuan A $(49,09)$. Hal ini dipengaruhi oleh ekstrak buah naga sebanyak $15 \%$, sedangkan pada perlakuan B $(50,89)$ dan C $(51,41)$ kandungan air lebih banyak dibanding perlakuan A. Karena ekstrak buah naga $20 \%$ dan $25 \%$, tingginya nilai kandungan kadar air pada perlakuan $\mathrm{C}$ yaitu dipengaruhi oleh ekstrak buah naga karena buah naga banyak mengandung kadar air. Kadar air menurut SNI 012354.2-2008 adalah 20-35\%. Berdasarkan hasil pengujian kadar air pada Gambar 7 menunjukkan bahwa kadar air mi basah tidak sesuai karena telah melebihi standar mutu kadar air yang ditetapkan. Kadar air sangat mempengaruhi daya tahan mi sagu. Kadar air yang tinggi akan mengakibatkan mudahnya bakteri dan jamur serta mikroba lainnya untuk berkembang biak, sehingga akan mempengaruhi mutu dari produk tersebut (Legowa dan Nurwanto, 2004).

\subsection{Profil Tekstur (kekerasan dan kelengketan)}

\subsubsection{Kekerasan}

Dari hasil uji analisa kekerasan mi sagu basah ekstrak buah naga dari tiga perlakuan dan tiga kali ulangan dapat dilihat pada Gambar 4.

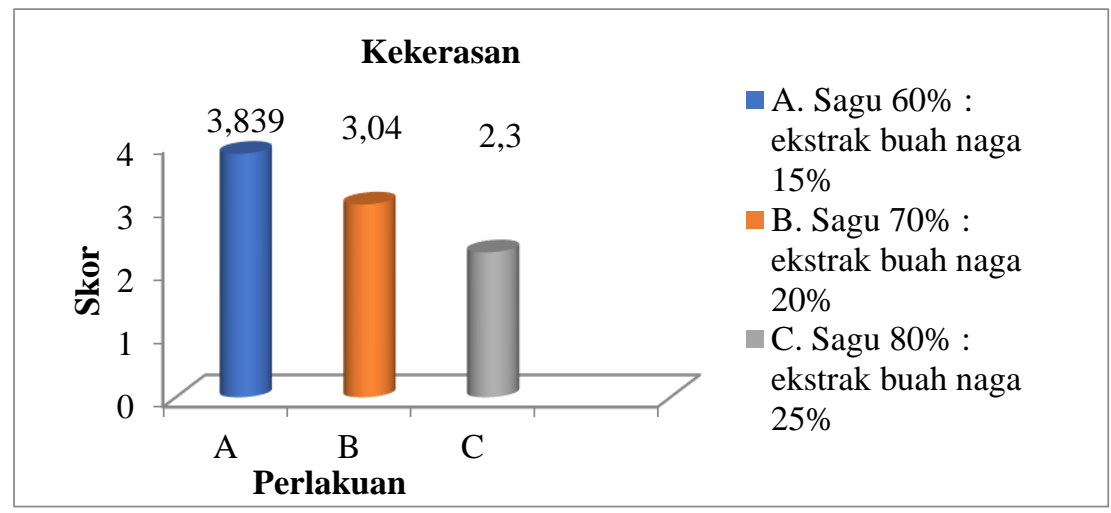

Gambar 4. Nilai kekerasan mi sagu ekstrak buah naga 
Berdasarkan Gambar 4, nilai kekerasan menunjukkan bahwa nilai $F_{\text {hitung }}$ (72.09) lebih besar dari $\mathrm{F}_{\text {tabel }}(0.05)$ yaitu 5.14 dan $\mathrm{F}_{\text {tabel }}(0.01)$ yaitu 10.92, dapat diartikan bahwa mi sagu berpengaruh nyata terhadap kekerasan sehingga dilakukan uji BNT. Dari uji BNT (0.05) menunjukkan bahwa mi basah pada perlakuan A berbeda signifikan dengan perlakuan B dan C. Begitu juga perlakuan B berbeda signifikan dengan perlakuan C. Pada perlakuan A menunjukkan nilai rata-rata yang tertinggi yaitu 3.893gf kemudian disusul oleh perlakuan B dengan nilai 3.040gf dan nilai rata-rata terendah yaitu perlakuan $\mathrm{C}$ dengan nilai 2.286. Kekerasan dipengaruhi oleh suhu, GMS dan interaksi antara kedua komponen tersebut. Respon kekesaran meningkat seiring peningkatan suhu dan konsentrasi GMS.

Hal ini ditunjukkan dengan konstanta yang bernilai positif. Selain itu, kekerasan menurun karena adanya interaksi suhu dan penambahan GMS. Hal ini ditunjukkan dengan konstanta yang bernilai negatif. Suhu ekstruder berpengaruh terhadap kekerasan pada produk mi sagu basah. Peningkatan suhu ekstruder dapat meningkatkan kekerasan mi sagu basah karena semakin tinggi suhu ekstruder menyebabkan tingkat gelatinisasi pati sagu semakin meningkat, sehingga amilosa yang keluar dari granula pati menyebabkan viskositas semakin tinggi (Engelen, $d k k$ 2015). Adapun pengujian nilai rata-rata analisa tekstur mi sagu dapat dilihat pada Tabel 2.

Tabel 2. Rata rata analisa tekstur mi sagu

\section{Kode Perlakuan Rata- rata (gf)}

\begin{tabular}{cc}
\hline A & $3,839.70 \mathrm{a}$ \\
$\mathrm{B}$ & $3,040.23 \mathrm{~b}$ \\
$\mathrm{C}$ & $2,286.43 \mathrm{c}$ \\
\hline
\end{tabular}

Ket : ${ }^{a}$ Angka-angka pada kolom yang berbeda diikuti oleh notasi yang sama tidak berbeda nyata pada taraf $5 \%$ dan $1 \%$ (uji BNT).

\subsubsection{Kelengketan}

Dari hasil uji analisa kelengketan mi sagu basah ekstrak buah naga dari tiga perlakuan dapat dilihat pada Gambar 5.

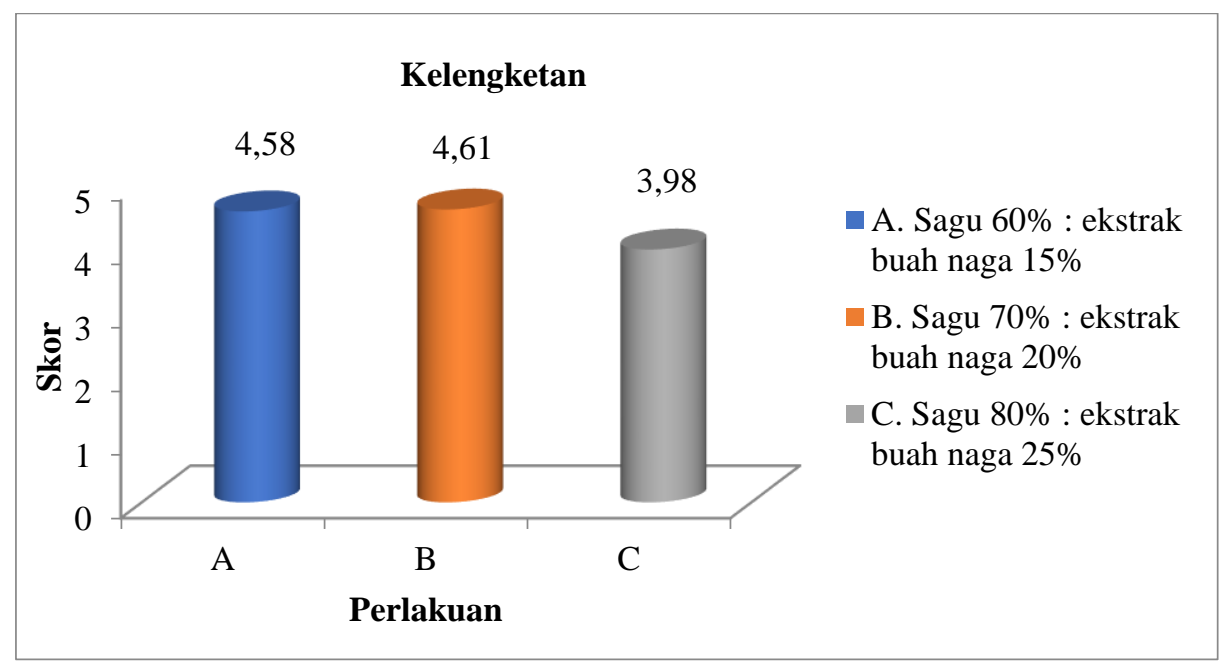

Gambar 5. Nilai kelengketan mi sagu ekstrak buah naga

Berdasarkan Gambar 5, nilai kelengketan menunjukkan bahwa mi basah pada perlakuan A sangat berbeda nyata dengan perlakuan $\mathrm{C}$, tetapi perlakuan A dan B tidak berbeda nyata. Pada perlakuan B menunjukkan nilai rata-rata yang tertinggi yaitu 4,61 gf kemudian disusul oleh perlakuan A dengan nilai 4,58 gf dan nilai rata-rata yang paling terendah yaitu $\mathrm{C}$ dengan nilai $3,98 \mathrm{gf}$

Kelengketan merupakan daya lengket yang ditunjukkan dengan besarnya gaya yang dibutuhkan untuk menarik bagian pangan dan memisahkannya dari lempeng kompresi. Nilai kelengketan yang rendah diharapkan dalam pembuatan mi. Model prediksi 
untuk kelengkatan mi sagu basah adalah model linier. Kelengketan dipengaruhi oleh GMS. Semakin tinggi konsentari GMS maka nilai kelengketan semakin meningkat. Hal ini ditunjukkan dengan konstanta yang bernilai positif. Penambahan GMS berpengaruh nyata terhadap respon kelengketan (Engelen, dkk 2015).

\subsection{Uji Organoleptik}

Hasil uji organoleptik yang dilakukan oleh 30 orang panelis yang tidak terlatih. Menunjukkan, dimana hasil dari uji organoleptik yang bertujuan untuk mengetahui tingkat kesukaan terhadap suatu produk olahan makanan. Parameter yang diuji yaitu aroma, rasa, tekstur dan warna terhadap mi basah yang tebuat dari sagu.

\subsubsection{Aroma}

Aroma makanan merupakan salah satu untuk menentukan daya indra penciuman konsumen terhadap suatu bahan makanan dapat memberikan aroma berbeda seperti makanan yang digoreng, dioven, dikukus ataupun direbus. Pada umumnya bau yang diterima oleh hidung dan otak lebih banyak merupakan berbagai ramuan atau campuran empat bau utama yaitu harum, asam, tengik dan hangus (Winarno, 2008). Hasil analisa aroma dapat dilihat pada Gambar 6.

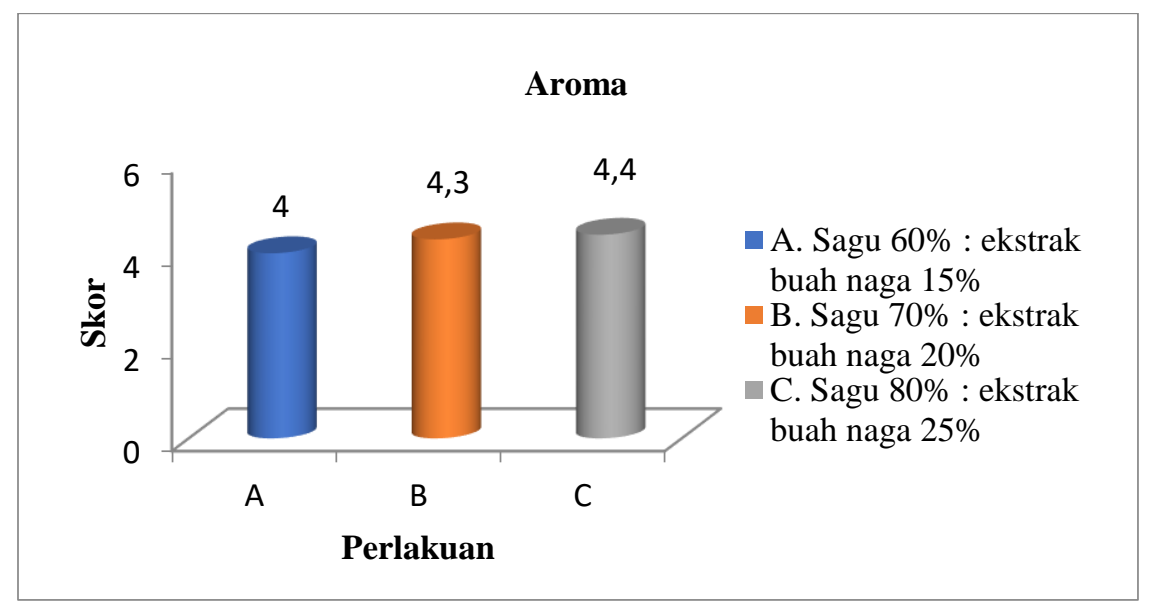

Gambar 6. Tingkat kesukaan aroma mi sagu ekstrak buah naga

Hasil uji organoleptik terhadap mi sagu basah bertujuan untuk mengetahui respon dari para panelis untuk mendapatkan nilai aroma yang dihasilkan. Menurut hasil uji organoleptik pada Gambar 11 nilai rata-rata tingkat kesukaan 4,4 adalah yang paling disukai oleh panelis. Karena campuran sagu dengan ekstrak buah naga lebih banyak pada perlakuan $\mathrm{C}$ (sagu 80\% dan ekstrak buah naga 25\%) dibandingkan dengan perlakuan A dan B.

Penggunaan sagu sebagai bahan baku dalam pembuatan mi basah sangat diminati oleh para panelis, karena disebabkan aroma alami sagu dan buah naga lebih timbul, akan tetapi berdasarkan hasil yang didapatkan aroma yang dihasilkan dari ketiga sampel banyak disukai bahkan sangat disukai oleh para panelis. Menurut Winarno (2004), bau makanan banyak menentukkan kelezatan makanan serta cita rasa bahan pangan itu sendiri. Walaupun suatu bahan pangan mempunyai nilai gizi yang tinggi, tetapi ketika tercium aroma tidak sedap tingkat kesukaan terhadap bahan pangan dapat menurun. Adanya aroma yang tidak sedap akan menimbulkan ketidaksukaan terhadap bahan pangan meskipun belum dikonsumsi.

\subsubsection{Rasa}

Rasa sebagai salah satu faktor utama dalam menentukan suatu produk dapat diterima atau tidak dikalangan konsumen, hal ini menjadi penting karena bahan-bahan yang digunakan menjadi syarat utama dalam menghasilkan sebuah cita rasa yang diinginkan. Menurut Soekarno (1985), rasa dapat dinilai sebagai tanggapan terhadap rangsangan yang berasal dari senyawa kimia dalam suatu pangan yang memberikan penilaian kualitas suatu produk selain dari pada nilai 
makanan. Hasil analisa rasa dapat dilihat pada Gambar

7.

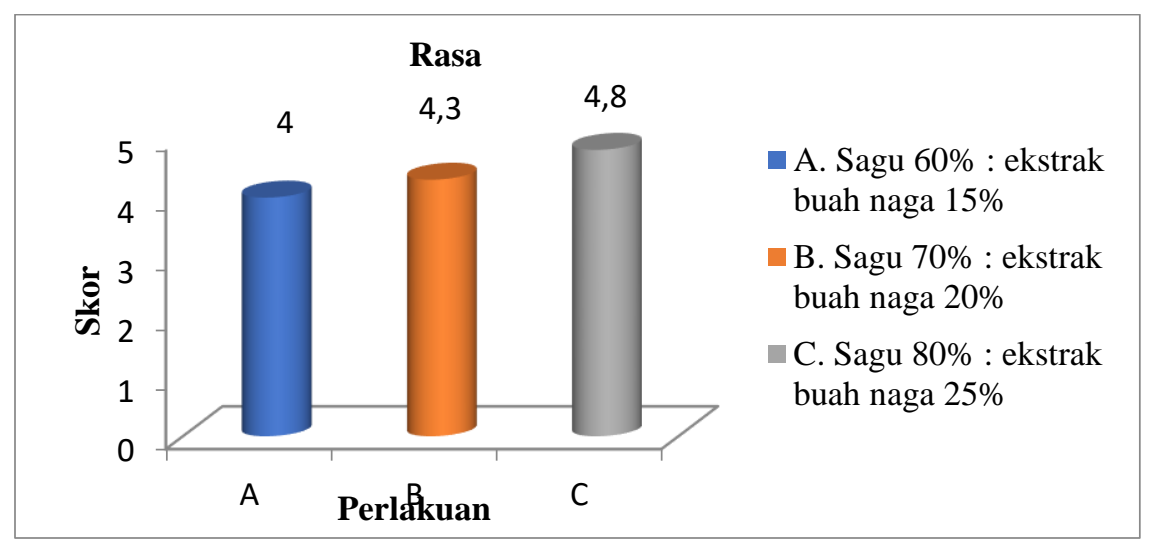

Gambar 7. Tingkat kesukaan rasa mi sagu ekstrak buah naga

Berdasarkan hasil uji yang telah dilakukan terhadap rasa mi sagu yang ditambahkan dengan buah naga didapatkan hasil rata-rata mencapai 4 hingga 4,8. Dapat diartikan bahwa, tingkat kesukaan dari panelis yaitu suka hingga sangat suka, karena rasa alami sagu dan ekstrak buah naga timbul pada saat dinikmati. Dari ketiga perlakuan terdapat satu perlakuan yang paling banyak disukai oleh para panelis yaitu pada perlakuan $\mathrm{C}$ dengan campuran (sagu $80 \%$ dan buah naga $25 \%$ ). Rasa merupakan parameter yang sangat penting dalam menentukkan tingkat penerimaan konsumen terhadap suatu produk makanan. Rasa yang enak dapat menunjang produk sehingga diterima oleh konsumen
(Erawaty, 2001).

\subsubsection{Tekstur}

Tekstur merupakan salah satu faktor terpenting pada setiap olahan makanan yang disajikan, makanan mempunyai tekstur masing-masing misalnya kekerasan, kelengketan, kerenyahan, elastilasi, kekenyalan, lunak dan lain sebagainya. Pencampuran bahan yang baik akan mendapatkan hasil yang baik pula untuk menghasilkan produk yang diinginkan, guna suatu alasan para konsumen untuk bisa menerima suatu produk yang bisa dikonsumsi atau tidak. Hasil analisa tekstur dapat dilihat pada Gambar 8.

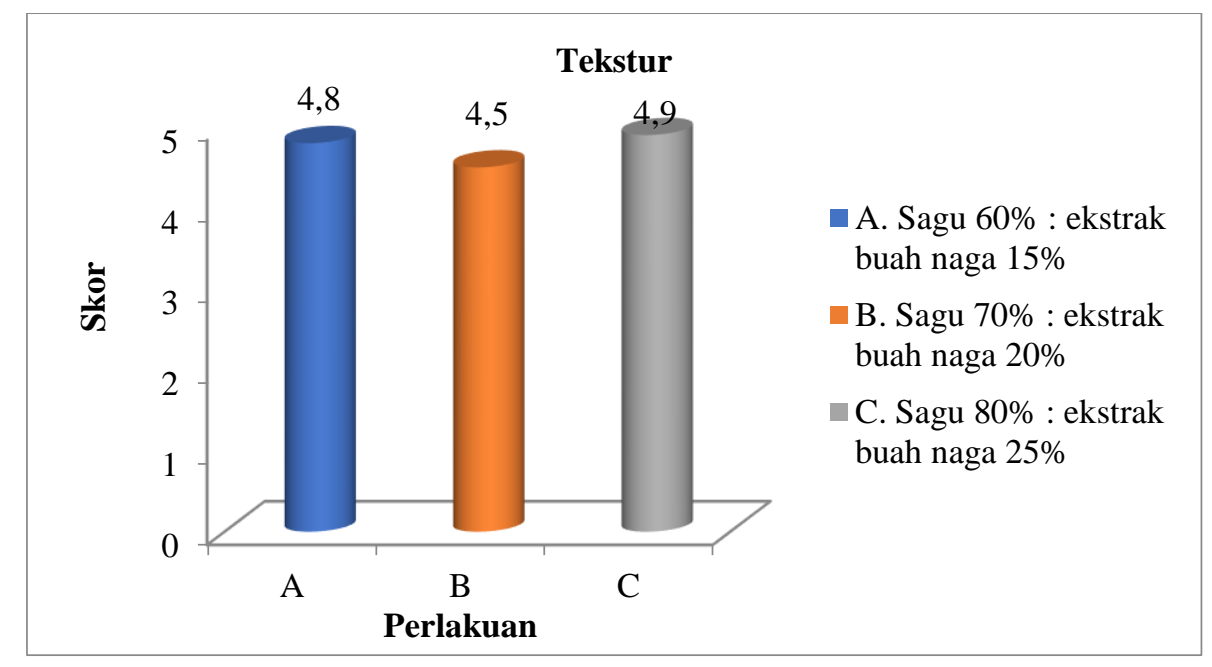

Gambar 8. Tingkat kesukaan tekstur mi sagu ekstrak buah naga 
Berdasarkan pengujian yang telah dilakukan terhadap tekstur dari mi sagu dengan pencampuran buah naga mendapatkan hasil rata-rata 4.8 sampai 4.9 yang diartikan bahwa panelis sebagian besar sangat suka terhadap tekstur mi sagu tersebut. Dari hasil uji organoleptik dapat dilihat bahwa perlakuan A dan C yaitu sangat disukai panelis dibandingkan dengan perlakuan $\mathrm{B}$, hal ini disebabkan oleh proses pencampuran/pembuatan adonan kurang kenyal (kalis) sehingga tekstur yang dihasilkan kurang maksimal atau kurang baik, tekstur dapat diraba atau dinilai dengan jari tangan. Setiap makanan mempunyai sifat tekstur tersendiri tergantung keadaan fisik, ukuran dan bentuknya. Tekstur merupakan penentuan terbesar mutu rasa (Kusuma, 2008). Tekstur yang dihasilkan dari pencampuran sagu dengan ekstrak buah naga dengan adanya proses glatinisasi dapat memberikan tekstur yang baik.

\subsubsection{Warna}

Warna pada makanan merupakan suatu daya tarik konsumen untuk dapat menerima atau menolak suatu produk makanan, seperti warna terhadap mi sagu ekstrak buah naga. Hasil pengujian organ oleptik terhadap warna mi sagu basha maka diperoleh perbandingan hasil yang dihasilkan dalam gambar berikut : Hasil analisa warna dapat dilihat pada Gambar 9.

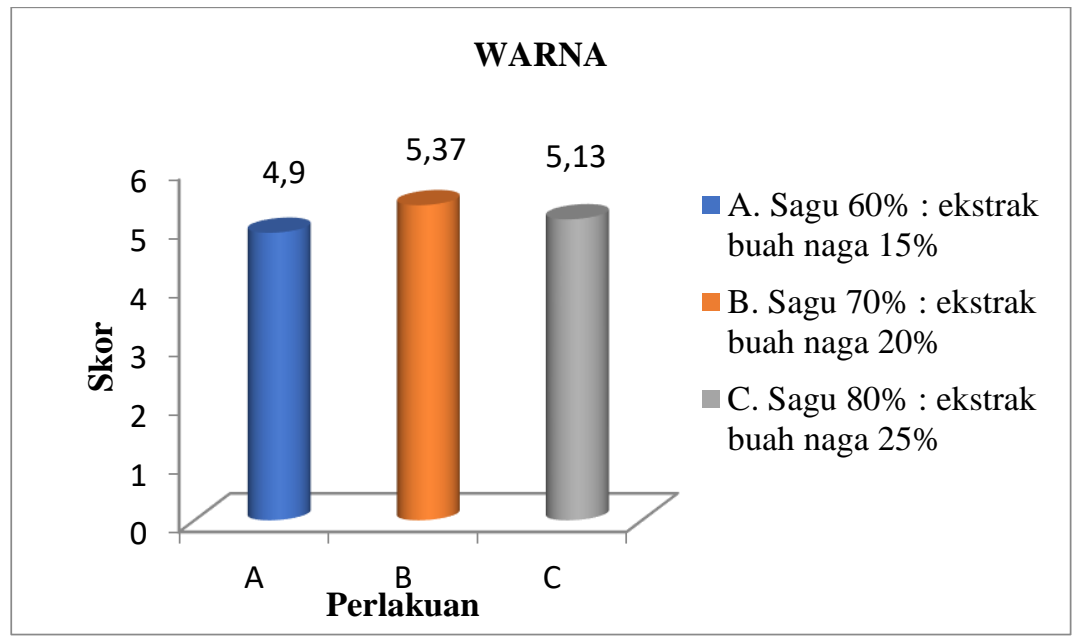

Gambar 9. Tingkat kesukaan warna mi sagu ekstrak buah naga

Berdasarkan hasil uji organoleptik terhadap warna mi sagu basah maka menunjukkan tingkat kesukaan panelis terhadap warna mi dan mendapatkan nilai rata-rata 4.9-5.13 artinya dari ketiga perlakuan yang telah diuji panelis berpendapat suka dan sangat suka karena warna pada mi (C) dengan campuran (sagu $80 \%$ : buah naga 25\%) sangat disukai panelis, hal ini disebabkan karena warna buah naga yang timbul. Winarno (2004) melaporkan bahwa selain sebagai

faktor yang ikut menentukan mutu, warna juga dapat digunakan sebagai indikator kesegaran atau kematangan. Baik tidaknya cara pencampuran atau cara pengolahan dapat ditandai dengan adanya warna yang seragam dan merata. Suatu bahan makanan yang bernilai gizi, enak dan teksturnya sangat baik kurang disukai apabila memiliki warna yang kurang sedap dipandang atau memberikan kesan telah menyimpang dari warna seharusnya.

\section{KESIMPULAN}

Kesimpulan pada penelitian adalah kombinasi terbaik mi sagu dengan penambahan ekstrak buah naga terdapat pada perlakuan ketiga (sagu 80\% :ekstrak buah naga 25\%) karena menghasilkan aroma, rasa, tekstur dan warna yang baik dan dapat diterima oleh panelis. 


\section{DAFTAR PUSTAKA}

Cahyadi W. 2009. Analisis dan aspek kesehatan bahan tambahan pangan. Penerbit Pt. Bumi Aksara. Jakarta. Edisi Kedua, Hlm 4.

Dewita., Lisan H., dan Syahrul. 2014. Kajian pengolahan mie sagu konsentrat protein ikan patin (Pangasius Hypophthalmus) instan yang difortifikasi tepung bayam (Amaranthus Sp). Jurnal. Universitas Riau.

Direktorat Gizi Departemen Kesehatan Ri. 1990. Daftar komposisi bahan makanan. Bharata Karya Aksara. Jakarta.

Engelen A., Sugiyono., dan Budijanto S. 2015. Optimasi proses dan formula pada pengolahan mi sagu kering (Metroxylon Sagu). Jurnal. Institut Pertanian Bogor Darmaga. Bogor.

Engelen A. 2017. Karakteristik kekerasan dan kelengketan pada pembuatan mi sagu basah. Journal Of Agritech Science. Vol 1 No 2. November. 2017.

Erawaty, R.W. 2001. Pengruh bahan pengikat, waktu penggorengan dan daya simpan terhadap sifat-sifat dan organoleptik produk nugget ikan sapu-sapu (Hyposascus Pardalis). Skripsi. Program Studi Teknologi Hasil Pertanian. Fakultas Perikanan Dan Kelautan. Bogor Institut Pertanian Bogor.

Hariyanto B. 2011. Manfaat tanaman sagu (Metroxylon $\mathrm{Sp}$ ) dalam penyediaan pangan dan dalam pengendalian kualitas lingkungan. Jurnal. Pusat Teknologi Agroindustri Bppt. Jakarta.

Hutching JB. 1999. Food color and apearance. Marylan: Aspen publisher Inc.

Kurniasari E, Wahyu S, Sugianti C. 2015. Mempelajari laju pengeringan dan sifat fisik mie kering berbahan campuran tepung terigu dan tepung tapioka. Jurnal Teknik Pertanian Lampung. 4(1): 1-8

Kusumawaty Y., dan Fitriani S. 2011. Kajian proses dan tingkat kesukaan konsumen terhadap mie sagu tradisional Riau. Jurnal. Universitas Riau.

Kusuma, D.S 2008. Pembuatan produk nasi singkong instan berbasis fermented cassavaflour sebagai bahan pangan pokok alternative. Skripsi. Departemen Ilmu Dan Teknologi Pangan, Fakultas Teknologi Pertanian. IPB. Bogor.

Legowa. A.M., dan Nurwantoro, 2004. Diklat kuliah analisis pangan. Program Studi Teknologi Hasil Ternak, Fakultas Peternakan Universitas Diponegoro. Semarang.

Masturi, Evaardinna, dan Yulianti, 2016, Ekstraksi kulit buah naga (Dragon Fruit) sebagai zat pewarna alami pada kain batik, jurnal, Pascasarjana UNNES.

Noviana. 2005. Analisa kualitatif dan kuantitatif zat Pewarna merah pada saus tomat dan Saus Cabe Yang Dipasarkan Di Pasar Lambaro Kabupaten Aceh Besar. Skripsi Fkm Usu. Medan.

Pancapalaga W. 2005. Pengaruh pemberian kaldu kupang terhadap kualitas gizi dan sensori kerupuk kupang. Laporan Penelitian. Lembaga Penelitian. Universitas Muhammadiyah Malang.

Purwani E.Y., Widianingrum H., Setyanto E.S., dan Thahir R. 2006. Teknologi pengolahan mie sagu. Jurnal Bb-Pascapanen Pertanian. 3(1):2-3.

Soekarno, S.T 1985. Penilaian organoleptik untuk industry pangan dan hasil pertanian. Bharata Karya Aksara. Jakarta.

Thahir R. 2004. Program Penelitian dan Pengembangan Teknologi Pangan Tradisional Untuk Mendukung Ketahanan Pangan. Balai Besar Penelitian dan Pengembangan Pascapanen Pertanian. Badan Litbang Pertanian. Hlm. 16-297.

Wahyuni R. 2012. Pemanfaatan buah naga super merah (Hylocereus Costaricensis) Dalam Pembuatan Jenang Dengan Perlakuan Penambahan Daging Buah Yang Berbeda. Jurnal., Universitas Yudharta Pasuruan.

Winarno, F.G. 2004. Kimia pangan dan gizi. P.T. Gramedia Pustaka Utama. Jakarta.

Yuliarti dan Nurheti. 2007. Awas bahaya dibalik lezatnya makanan. Yogyakarta. 